\title{
Danmark som \\ arktisk stormagt
}

\section{Martin Breum}

Dansk udenrigspolitik er i færd med et støt skifte mod nord. I januar slog regeringens særlige udenrigspolitiske rådgiver, Peter Taksøe-Jensen, fast, at et stærkt engagement i Arktis er afgørende for nationens interesser: "Danmark er sammen med Grønland og rigsfællesskabet en arktisk stormagt. Vi skal bruge endnu flere kræfter på at sikre, at udviklingen i Arktis kommer til at stemme overens med danske interesser", sagde han til Politiken. Få dage senere bekræftede udenrigsminister Kristian Jensen, at staben omkring den arktiske ambassadør i Udenrigsministeriet nu udvides.

Den norske regering under Jens Stoltenberg, NATOs nuværende generalsekretær, gjorde allerede i 2005 'Nordområdepolitikken' til hovedanker i norsk politik, og da udenrigsminister Per Stig Møller i 2008 inviterede de øvrige arktiske kyststater, USA, Canada, Rusland og Norge til topmøde i Ilulissat i Grønland, høstede dansk diplomati både hæder og nyttig erfaring: På topmødet bekræftede de fem stater deres fredelige hensigter i Arktis, og de fik knæsat deres egne, særlige rettigheder i regionen. Ilulissat-erklæringen er fortsat en milepæl i nyere arktisk historie. Peter Taksøe-Jensen var chef for den task force i Per Stig Møllers ministerium, der forberedte mødet i Ilulissat. Et par måneder senere anbefalede Erling Bjøl i Politiken et øget fokus mod 'Nordkalotten' som afløsning for jagt på 'guerillakæmpere i et ukendt asiatisk bjergland'. Han havde forinden indhentet råd bl.a. fra flådens daværende, Forsvarsakademiets nuværende chef, kontreadmiral Nils Wang, der i en årrække har argumenteret aktivt for det skifte mod nord, vi nu ser.

Når det nye fokus på Arktis alligevel for nogle måske virker overraskende, skyldes det formentlig, at det siden Anden Verdenskrig har været kutyme blandt landets ledere at nedtone Grønlands betydning for Danmark. Statsminister H.C. Hansen indgik i 1957 en hemmelig aftale, der gav USA adgang til at opmagasinere atomvåben i Thule, og der har i det hele taget været et geopolitisk element i Danmarks interesser i Grønland, som skiftende regeringer har valgt at pleje uden for megen offentlighed.

Martin Breum er journalist og en af Danmarks førende iagttagere af udviklingen i Arktis og af rigsfællesskabet. Han er forfatter til bøgerne 'Når isen smelter' og 'Balladen om Grønland'. 
Det er ikke sket tidligere i menneskets historie, at et helt ocean, der før var utilgængeligt, pludselig åbner sig for almindelig menneskelig aktivitet. Sammen med globaliseringen - især efterspørgslen på mineraler, fødevarer og energi - gør isens forsvinden Arktis stadig mere central for verdenssamfundet.

Denne lavmælthed er under opløsning. Da SR-regeringens udenrigsminister Martin Lidegaard i 2014 blev spurgt, hvilken betydning, rigsfællesskabet med Grønland har for Danmark, lød svaret: "Den indflydelse, vi har på de internationale regler og den politik, der skal føres i Arktis i fremtiden, er rigtig meget værd i geopolitisk forstand. Det betyder, at vi bedre kan forfølge Danmarks overordnede udenrigspolitiske interesser og mål. Vi kan arbejde for trygge rammer for Danmark, arbejde på at den danske befolkning kan leve i sikkerhed; vi kan sikre multilaterale rammer, der skaber så store muligheder for små landes indflydelse som muligt, fredelig konfliktløsning, godt miljø og en socialt afbalanceret udvikling. Alle disse helt vitale interesser får vi en mulighed for at varetage aktivt, fordi vi er forbundet med Grønland. Uden Grønland kunne vi ikke tillade os nær samme styrke i stemmeføringen, og det gælder også ud over den arktiske region - bare i lidt mere overført betydning”. Synspunktet blev gentaget på tv.

Statsminister Lars Løkke Rasmussen sagde det samme - bare kortere - på et pressemøde med Grønlands og Færøernes politiske ledere kort efter nytår: "Det giver en rolle i verdenssamfundet, der er klart større end den rolle Danmark kunne opnå alene, Grønland kunne opnå alene, Færøerne kunne opnå alene”.

\section{Strategien}

Norges fokus er på naboskabet til Rusland, den fortsatte udvikling af olie- og gas stadig længere mod nord og det lukrative fiskeri. Danmarks interesser i Arktis er knap så firskårne, men defineres ganske bredt, sådan som det blev gjort i kongerigets første arktiske strategi fra 2011. Danmark skal først og fremmest bidrage til at fastholde Arktis som en fredelig region, hvor udnyttelsen af de naturlige ressourcer og nye muligheder mineraler, olie, gas, fisk, nye handelsruter m.v. - forfølges i stringent balance med hensynet til klimaet og det arktiske miljø og til stadig gavn for de arktiske folkeslag. (Der bor cirka fire mio. mennesker nord for Polarcirklen, heraf ca. 500.000 medlemmer af de arktiske folk). Hertil skal lægges Danmarks klare interesse i at fastholde rigsfællesskabet med Grønland og Færøerne.

Disse brede mål kan lyde en kende banale, og det vil være vanskeligere for en dansk regering af overbevise offentligheden, end det har været for skiftende norske regeringer, men det er værd at huske på, hvad der er på spil - og på en række velvoksne snubletråde.

Det er ikke sket tidligere i menneskets historie, at et helt ocean, der før var utilgængeligt, pludselig åbner sig for almindelig menneskelig aktivitet. Sammen med globaliseringen - især efterspørgslen på mineraler, fødevarer og energi - gør isens forsvinden Arktis stadig mere central for verdenssamfundet. Derfor ser vi nu, hvordan de involverede stater øger deres indsatser for at opnå indflydelse i Arktis; på de nye handelsruter mellem Asien, Euro- 
pa og USA; på de nye muligheder for militær mobilitet mellem Atlanterhavet og Stillehavet; adgangen til mineraler, olie og gas og til de arktiske fiskefarvande, der hører til klodens rigeste.

De arktiske nationer har for længst erkendt, at udviklingen kræver et intensiveret samarbejde, hvis alt skal gå vel: Regionens egentlige stormagt og den stærkeste militære magt i Arktis er Rusland, der andre steder på kloden p.t. forfølger sine interesser på uforudsigelig vis og som føler en særlig historisk og geografisk adkomst til Arktis. De sidste grænser i Det Arktiske Ocean er endnu ikke på plads; ingen ved præcis, hvem retten til de sidste stykker havbund omkring Nordpolen tilhører. Klimaforandringerne ændrer løbende regionens geografi og gør Arktis til genstand for nervøs, global interesse.

En række stærke aktører uden for regionen - Kina, EU, Japan, Korea, Indien har længe fastholdt, at de har legitime krav på indflydelse, bl.a. fordi de nye arktiske handelsruter og rystelserne i det arktiske klima har globale implikationer. Hensynet til miljøet kræver desuden rigid regulering af alt fra fiskeri til olieefterforskning, og her er der ikke altid enighed om tilgangen.

I en sådan dynamik, hvor store magters interesser er i spil, har småstater som Danmark en særlig interesse i stærk international regulering og velsmurte fora for fælles diskussion m.v. (se Berthelsens og Raschs artikel senere i dette nummer af Udenrigs). Endelig gælder særligt for Danmark et helt aktuelt behov for at udbygge det gode forhold til Grønland og Færøerne, så rigsfællesskabet fortsat kan træffe beslutninger i fællesskab, Danmark kan fastholde sin indflydelse i verdens- samfundet, og de familiemæssige og kulturelle bånd bevares.

\section{Indflydelse}

Spændingen mellem overskrift og reelt Rigsfællesskabet gør det muligt for danske regeringer, ministre, politikere, forretningsfolk, officerer og forskere at øve kontinuerlig indflydelse og pleje Danmarks specifikke interesser i Arktis. Det giver adgang til samarbejder, som Danmark ellers ikke ville have adgang til, og som giver indflydelse også uden for Arktis.

Sikkerhedspolitisk gælder, at Grønland i geografisk forstand er en del af Nordamerika. Grønland har siden starten af 1800-tallet været tænkt ind i USA's forsvarspolitik. Thule-basen hører fortsat til de vigtigste radarinstallationer i USA's missilforsvar og som modtagestation for signalerne fra USA's spionsatellitter (se Lidegaards og Vedbys bidrag om USA og sikkerhedspolitikken i Arktis).

Denne arktiske forbindelse mellem USA og Danmark er en del af forklaringen på de voksende kontakter, der for tiden udvikles mellem dansk forsvar, FE, Arktisk Kommando m.v. og USA's militære værn og agenturer. Chefen for Arktisk Kommando, Kim Jesper Jørgensen, melder om en sværm af nye kontakter i USA, der ønsker at samarbejde; senest bl.a. The Office for Naval Research: Det danske forsvar får fremover formentlig fornyet adgang til den forskning, som ONR's mere end 2000 akademikere udfører.

Danmark deltager som naturligt medlem i en række internationale fora, der bidrager til reguleringen i Arktis. Især er det afgørende, at kongeriget er én af kun otte medlemsstater i Arktisk Råd de førnævnte fem plus Finland, Sverige og Island. Danske ministre og embeds- 
mænd mødes her med beslutningstagere fra USA, Rusland og de øvrige på en facon, der er vanskelig at forestille sig i andre regi.

Da udenrigsminister Kristian Jensen var i Alaska til en Arktiskonference i august 2015, mødtes han flere gange med USA's udenrigsminister John Kerry og kunne face-to-face invitere præsident Obama til Grønland. Anekdotisk, javist, men illustrativt for de muligheder, det arktiske samarbejde løbende giver. Arktisk Råd optog i 2014 de store asiatiske økonomier som permanente observatører, så også den vej breder Danmarks arktiske kontaktflade sig; det er vigtigt også fordi Færøerne og Grønland er stærkt optagede af at øge deres fiskeeksport mod øst.

Arktisk Råd nedsætter løbende nye task forces, hvis anbefalinger retter sig direkte mod de otte arktiske regeringer. Det gælder fx for beredskab mod olieforurening, samarbejde om søredning, ny anvendelse af telekommunikation og anvendelse af satellitter, miljøregulering m.v. Arktisk Råd har også en væsentlig del af æren for et sæt nye, skrappere krav til skibe, der vil sejle i Arktis.

Danmark er sammen med Norge, USA, Canada og Rusland i disse måneder frontløber i et nyt initiativ, der skal sikre Det Arktiske Ocean mod kommercielt fiskeri, indtil konsekvenserne af klimaforandringerne er bedre kendte. Her er tale om noget så usædvanligt som et forebyggende miljøinitiativ, og EU, Kina, Island, Japan, og Sydkorea er nu også ved at blive forpligtet.

Danske forskere er centralt involveret i langvarige projekter om alt fra klima til kommunikation. De har adgang til forskningsresultater i verdensklasse og indflydelse på konklusionerne, og de er med til at udbygge Danmarks politiske pondus i Arktis. Science diplomacy er et væsentligt drivmiddel i det arktiske samarbejde, og dansk polarforskning bygger på en lang og stærk tradition.

Fhv. forskningsminister Esben Lunde Larsen markedsførte i december 2015 sammen med ca. 20 danske forskere denne danske kompetence i Bruxelles: Her var målet særligt at øge EU's investeringer i arktisk forskning, men indflydelsen rækker længere. EU's Udenrigstjeneste bad i 2015 netop Danmark om at bidrage med input til Arktis-afsnittet i EU's kommende, globale strategi, og udenrigsministeriet bidrager sammen med Grønland og Færøerne også til et mere detaljeret udspil fra Europa-Kommissionen om EU's indsats i Arktis, der ventes færdig i Bruxelles senere i år.

Danmark er i kraft af Grønland og sit EU-medlemskab et oplagt bindeled for EU til Arktis, og det danske embedsværk bistår altså i øjeblikket EU med at opnå den indflydelse i Arktis, Bruxelles har kæmpet for i en årrække.

\section{Arktisk bonanza?}

Har dansk erhvervsliv tilsvarende muligheder i denne dynamik? Her er signalerne mindre entydige. På det seneste World Economic Forum i Davos spåede den amerikanske investeringsfond Guggenheim Partners om multi-milliard-investeringer især i infrastrukturen i Arktis. Den danske regerings Vækstfond var i 2015 på turné i Grønland for at gøde jorden for nye erhvervsprojekter, ejerskifter m.v.

DI og Grønlands Erhverv har længe bragt danske virksomheder sammen i en arktisk råstof-klynge for at forberede dansk engagement især i Grønlands minesektor, og et nyt arktisk maritimt netværk 
I dag er det dog ikke kun nationalstatslig nationalisme der eг på fremmarch, men også nye regionale nationalbevægelser. Bevægelser som den skotske, katalanske og mange andre er ikke tilfredse med blot at opnå regionalt selvstyre indenfor deres 'egne' stater, men vil skrive historien om tilbage til henholdsvis 1714 (Katalonien) og 1707 (Skotland) og blive 'rigtige' nationalstater og fuldgyldige medlemmer af Eப. Det er ikke lykkedes - endnu. Men kravet om fuld selvstændighed foreligger og formuleres stadig kraftigere, jo mere det afvises.

for rederierne og andre fra 'Det Blå Danmark' er i sving i DTU-regi. Danmark leder netop nu sammen med Norge en task force i Arktisk Råd, der ser på nye kommunikationsteknologiske løsninger i Arktis; her er dansk erhverv godt rustet.

Advokatfirmaet Horten havde i januar mere end udsolgt til et træf om mulighederne for offentligt-privat samarbejde om store infrastrukturprojekter i Grønland. Pensionskasserne lurepasser, men holder sig parate, og danske rederier har for længst investeret milliarder i isforstærkede skibe $\mathrm{i}$ forventning om vækst på de arktiske fragtruter mellem Europa og Asien. Ruterne nord om Rusland og nord om Canada åbner sig i takt med polarisens forsvinden og vil være langt kortere - og derfor kræve langt mindre brændstof - end turen gennem Suez- og Panamakanalen. Endnu er de nye ruter kun farbare få måneder om året, men Danmark har ikke råd til at sidde udenfor. Flyttes bare få procent af verdenshandlen over på de arktiske fragtruter, kan det skabe væsentlige nye muligheder for rederierne.

Dansk erhvervsliv har kulturelle, sproglige og andre fortrin i Grønland, der gerne samarbejder med danske virksomheder. Naalakkersuisut, selvstyreregeringen i Nuuk, ønsker en ny international landingsbane i Sydgrønland og en i Nuuk. En ny havn til 430 mio. kroner er under opførelse i Nuuk med Per Aarsleff A/S som entreprenør og Rambøll som hovedrådgiver. Det er det største havneprojekt i Rambølls historie. Langtidsudsigten for Grønlands offentlige økonomi er stadig dyster, men turismen og beskæftigelsen er i vækst.

En række mineraler i Grønland står højt på den europæiske industris ønskeliste, og mineindustrien er i bedring, trods aflyste storskalaprojekter: En lille rubinmine indleder snart produktion syd for Nuuk; en anden mine synes på vej nær Kangerlussuaq og et australsk firma vil udvinde zink længst mod nord. Uranen skiller vandene i Grønland, men er stadig på den politiske dagsorden: Selskabet GME ventes at bede om udvindingstilladelse i år. De store fiskerivirksomheder melder om rekordoverskud, og nye fiskearter finder vej i takt med klimaets udsving: Fornylig kunne man smage grønlandsk tun.

Grønland har nogle af verdens rigeste fiskevande, store mængder vandkraft, store potentialer for ferskvandsproduktion og arktisk blue-tech: Bioteknologiske virksomheder arbejder fx i øjeblikket på at udvikle koldtvandsenzymer fra Grønland, der kan gøre det muligt at vaske tøj - eller industrianlæg - ved lave temperaturer. Endelig olien og gassen: Geologerne spår, at nogle af verdens største, endnu uidentificerede forekomster ligger under den grønlandske havbund, bl.a. ud 
for Nordøstgrønland, hvor geologien svarer til den norske Nordsøsokkel. Ingen ved, om det igen bliver rentabelt at udnytte disse ressourcer; flere olieselskaber har trukket sig ud af Grønland, men Selvstyret er stadig optimistisk.

Den korte udlægning må lyde: Der er langt mellem realiserede erhvervseventyr i Arktis, men potentialerne er svære at overse.

\section{Grønland har nøglen}

Visionen om Danmark som led i en arktisk stormagt holder selvsagt kun, så længe rigsfællesskabet fungerer. Professor Rasmus Gjedssø Bertelsen fra Tromsø Universitet påpeger gerne, at Danmark også har et potentiale til at blive verdens første post-arktiske nation. Uden Grønland vil Danmark miste 98 pct. af sin landmasse og enhver betydning som arktisk aktør.

Også derfor er det værd at huske på, at rigsfællesskabet stadig fungerer udmærket i det daglige. Selv svære konflikter løses i mindelighed: Efter to års alvorlig strid indgik Danmark og Grønland i februar et omfattende sæt aftaler om, hvordan eventuel udvinding og eksport af uran fra Grønland skal reguleres. (Nuuk roste ligefrem det danske diplomati; det sker ikke ofte). Hverdagen fungerer godt, og Grønlands og Færøernes stilling i riget udvikler sig støt.

Danmarks særlige udfordring består $i$ at kombinere dette daglige samarbejde med det faktum, at mange grønlændere og færinger fortsat mener, at rigsfællesskabet i sin nuværende form på sigt bør opløses og erstattes af et mere frivilligt (men gerne traktatfæstet) samarbejde. De nærer dyb skepsis over for ethvert tilløb til øget dansk kontrol eller indskrænkning af deres egne kompetencer
- ikke mindst de udenrigspolitiske kompetencer eller rettigheder til undergrunden, der er forhandlet på plads siden Anden Verdenskrig. Færøerne fik udvidet adgang til at indgå aftaler med fremmede magter og organisationer i 2005; Grønland har opnået samme art beføjelser og særligt med Selvstyreloven af 2009. (Se Vittus Qujaukitsoqs artikel senere i dette nummer af Udenrigs)

Grønlænderne blev i 1985 - imod danske ønsker - de første nogensinde til at melde sig ud af EF/EU, og Nuuk har siden presset på for at få større indflydelse på rigets udenrigspolitiske praksis. $\mathrm{Da}$ grønlænderne med Selvstyreloven overtog den fulde ret til råstofferne i Grønland, stod retten til en mere selvstændig udenrigspolitik som det næste på prioriteringslisten. Grundloven siger, at udenrigs- og sikkerhedspolitik er et anliggende for den danske regering, men loven er flere gange blevet bøjet efter nordatlantisk pres, og kravet om yderligere nyfortolkning er konstant. Landsstyret i Torshavn valgte allerede i 1974 at stå helt udenfor EF, og en del færøske politikere sætter konsekvent betegnelsen 'det såkaldte' foran 'rigsfællesskab'.

Der er også ind imellem uenighed om konkrete elementer af udenrigspolitikken; fx eksporten af uran fra Grønland og EU's sanktioner mod Rusland, som Færøerne har valgt at drage nytte af. Grønlands og/eller Færøernes udmeldelse af rigsfællesskabet er stadig kun ét af mange mulige fremtidsscenarier og helt uden fast tidsplan, og selv de mest iltre tilhængere af løsrivelse i Grønland ønsker som nævnt tæt samarbejde med Danmark, også efter en eventuel opløsning af rigsfællesskabet som vi kender det. Men alt er alligevel ikke ved det gamle. 


\section{Et folk efter folkeretten}

Danmark anerkendte med Selvstyreloven i 2009 grønlænderne som et folk i folkerettens forstand, og de fik ret til at frigøre sig af rigsfællesskabet, når de ønsker det. Tre ud af fire nordatlantiske medlemmer af Folketinget repræsenterer en stabil selvstændighedstrang på Færøerne og i Grønland. Færøerne førte for bare 16 år siden (kuldsejlede) forhandlinger med København om løsrivelse, og i begge nationer arbejder man nu på nye, lokale grundlove dog inden for rigsfællesskabets rammer.

De mange eksempler på selvstændighedstrangen har fået udenlandske iagttagere til at ane en fremtid, hvor Danmark måske ikke længere er den væsentligste partner for de to øsamfund; en forandring, som også grønlandske politikere som det nuværende folketingsmedlem for Siumut, Aleqa Hammond, gerne varsler.

I det amerikanske militære fagtidsskrift Proceedings Magazine fra december 2015 tegnes et fremtidsscenarie, hvor Grønland løsriver sig fra Danmark, mens kinesisk industri og militær indtager en hovedrolle. Det er en stærkt misvisende spådom, der savner indsigt i den politiske kultur og praksis i Grønland og i rigsfællesskabets natur, men det indeholder en snert af virkelighed. Forsvarets Efterretningstjeneste, FE, deler uroen over Kinas voksende interesse for Grønland, og mange grønlændere ønsker som nævnt en ny ramme om samarbejdet. Her lurer en uklarhed om rigsfællesskabets fremtid, som førnævnte Nils Wang fra Forsvarsakademiet, tidligere udenrigsminister Uffe Ellemann-Jensen og andre er optagede af, men som hidtil ikke har affødt synlig bekymring i Nuuk (se Mikkel Vedbys artikel senere i dette nummer af Udenrigs).
På andre fronter forstærkes rigsfællesskabet: Danmark og Grønland fremsatte i december 2014 et spektakulært fælles krav til FN's såkaldte sokkelkommission om retten til 895.000 kvadratkilometer havbund fra Grønlands 200-sømilsgrænse over Nordpolen og helt til den russiske sømilegrænse. (Området er knap 20 gange Jylland, Fyn og øerne til sammen.) Her lød et tydeligt signal om, at Danmark er parat til at gå langt for at sikre Grønlands interesser i Arktis. Kravet blev langt større end oprindeligt planlagt, og det er udtryk for en vis risikovillighed, idet Rusland har overlappende interesser i Det Arktiske Ocean.

Der forestår nu 10-20 års afklaring i FN-regi og dernæst formentlig forhandlinger mellem Rusland og Danmark/Grønland (og måske Canada) om grænsedragningen på bunden ved Nordpolen. Resultatet er uforudsigeligt, men ét er sikkert: Uanset hvor stort et stykke havbund kongeriget måtte vinde retten til, består gevinsten primært af adgang til eventuelle mineraler, olie eller gas på havbunden; et privilegium, der straks vil tilfalde Grønland. Det fulde ejerskab til råstofferne i Grønland blev som nævnt overført til det grønlandske folk i 2009.

Havet i de centrale dele af Det Arktiske Ocean er mere end 4000 meter dybt, og den tilgængelige viden fra området tyder ikke på tilstedeværelsen af olie, gas eller mineraler af værdi, men det dansk-grønlandske krav er både i Danmarks og Grønlands øjne udtryk for sund, rettidig omhu. Man tager hvad man kan, for ingen ved, hvad man måtte finde i dybet i fremtiden - og i øvrigt er antagelsen, at det styrker både Grønland og Danmark, hvis nationen bliver endnu større, end den er i forvejen. 
